\title{
ASSESSING THE CHANGE IN COVER OF NON-INDIGENOUS DWARF-PINE USING AERIAL PHOTOGRAPHS, A CASE STUDY FROM THE HRUBÝ JESENÍK MTS., THE SUDETES
}

\author{
VÁCLAV TREML ${ }^{1}$ JAN WILD $^{2,4}$, TOMÁŠ CHUMAN ${ }^{1}$, \\ MARKÉTA POTŮČKOVÁ ${ }^{3}$
}

\begin{abstract}
${ }^{I}$ Department of Physical Geography and Geoecology, Faculty of Science, Charles University in Prague, email: treml@natur.cuni.cz

${ }^{2}$ Institute of Botany, Academy of Sciences of the Czech Republic, Prague

${ }^{3}$ Department of Applied Geoinformatics and Cartography, Faculty of Science, Charles

University in Prague

${ }^{4}$ Department of Applied Geoinformatics and Spatial Planning, Faculty of Environmental Sciences, Czech University of Life Sciences, Prague
\end{abstract}

Received: $30^{\text {th }}$ August 2010, Accepted: $28^{\text {th }}$ February 2011

\begin{abstract}
In addition to ongoing climate change, alpine ecosystems are also threatened by the expansion of non-indigenous species. Expansion of dwarf pine (Pinus mugo Turra) in the Hrubý Jeseník Mts. is an excellent example of the interactions between a planted alpine shrub and alpine ecosystems dominated by grassland species. Based on a comparison of aerial photographs taken in two different periods (1971/73 and 2003) we analyzed spatial changes in the dwarf pine cover. We focused on an evaluation of the current proportion of dwarf pine stands above the upper forest limit, as well as on the effects of stand texture and environmental variables on dwarf pine expansion over this 30 year period. During this time, dwarf pine stands increased their extent by 63\%. Small forest-free areas above the upper forest limit in the northern part of the Hrubý Jeseník ridge are currently covered by dwarf pine on more than $30 \%$ of their surface. Expansion of dwarf pine was fastest in open, finegrained stands, often situated in lower altitudes and on north- to east-facing slopes. The dwarf pine expansion was more intense than predicted by simple model of vegetative growth, especially within open stands with short polycormon margins in low altitudes. This might be explained by more intensive growth in less extreme environment and/or by higher generative reproduction on these sites. Finally, we suggest that expanding dwarf pine shrubs and recessing grassland patches negatively affects the abundance of heliophilous alpine plants and insects. We believe that the results of this study could be relevant to ongoing discussions on the management of summit forest-free areas in the Hrubý Jeseník Mts.
\end{abstract}

Keywords: Pinus mugo, expansion, Sudetes, Hrubý Jeseník, object-based classification, aerial photographs 


\section{INTRODUCTION}

Dwarf pine (Pinus mugo Turra) is an alpine shrub that occurs mainly in east and central Europe (Businský 1998, Hamerník and Musil 2007). Polycormic growth and clonal spreading are characteristic for this species. In addition, it is a successful invader into grassland communities (Dullinger et al. 2003).

Dwarf pine has been frequently planted in deforested or steep-sloping mountain areas, in order to protect soils against mass movement and to increase the overall rate of evapotranspiration (e.g. Sokol 1965). This is also the case in the Hrubý Jeseník Mts. (Sudetes, Czech Republic), where it was planted on summit grasslands since the middle of the nineteenth century (Hošek 1964). Strong competitive pressure of expanding dwarf pine shrubs has probably led, however, to decreases in the abundance of heliophilous alpine plants and insects (e.g. Bureš and Burešová 1989, Kuras et al. 2001). The dynamics of dwarf pine expansion may thus be an important issue from the viewpoint of nature protection.

Spatial differences in dwarf pine expansion depend on several variables, such as terminal growth, production of ramets, germination, competition with hemicryptophytes and disturbances (Štursa 1966, Wild and Wildová 2002, Wild and Winkler 2008). The influence of individual factors is also affected by stand age and the rate of intraspecific competition (Souček et al. 2001, Wild and Winkler 2008).

The main objective of the present study is to evaluate spatiotemporal changes in dwarf pine cover. In addition, we attempt to assess the possible influence of both environmental variables and variables describing dwarf pine textural properties on spatial inequalities in dwarf pine expansion. This study is based on a comparison of dwarf pine cover between 1971/1973 and 2003, which was selected as a compromise between the limited number of available aerial photographs of sufficient quality and the optimal length of time needed to evaluate changes. The thirty-year time span enables a gross estimation of dwarf pine spatial dynamics covering both short-term expansions and declines.

As part of this main objective, we (a) determined the recent cover of dwarf-pine stands and their percentage proportion on the overall extent of forest-free summit areas; (b) ascertained changes in the dwarf-pine cover during the last 30 years at selected sites; and (c) evaluated the effects of environmental and textural variables on dwarf pine expansion.

\section{METHODS}

\section{Study area}

Hrubý Jeseník is an old Hercynian mountain range culminated by the highest peak Praděd at $1491 \mathrm{~m}$ a.s.l. (Fig. 1). The highest elevations are considered to be naturally forest-free (Jeník 1961), however the extent of grasslands was significantly enlarged by human activities in the past (Novák et al. 2010).

The study area is characterized by relatively high precipitation (around $1300 \mathrm{~mm}$ per year). Average annual temperatures oscillate around $1.1^{\circ} \mathrm{C}$ in the summit regions. Gently undulated, high-elevated plateaus are characterized by high winter precipitation (100 to $200 \mathrm{~cm}$ deep snow pack) and strong westerly winds, which sweep snow away from convex parts of the terrain.

The montane forests are formed by Norway spruce (Picea abies [L.] Karst.) and grade into alpine grasslands at the alpine treeline ecotone. The actual upper forest limit is situated at approximately $1310 \mathrm{~m}$ a.s.l. (Treml and Banaš 2000). Summit forest-free areas are covered by grasslands dominated by graminoids (e.g. Festuca supina, Nardus stricta, 
Calamagrostis villosa, Calamagrostis arundinacea, Avenella flexuosa) and ericoid shrubs (Vaccinium myrtillus, V. vitis-idaea). Scattered shrubs of juniper (Juniperus communis ssp. alpina) also occur in the summit grasslands. Non-indigenous dwarf pine (Pinus mugo) was planted during the 19th and 20th century in $1.25 \times 1.25 \mathrm{~m}$ up to $2 \times 2 \mathrm{~m}$ square spacing, with the most extensive planting occurring between the years 1874 and 1928 (Hošek 1973).

Fig. 1: Study area and the extent of dwarf pine stands in 2003

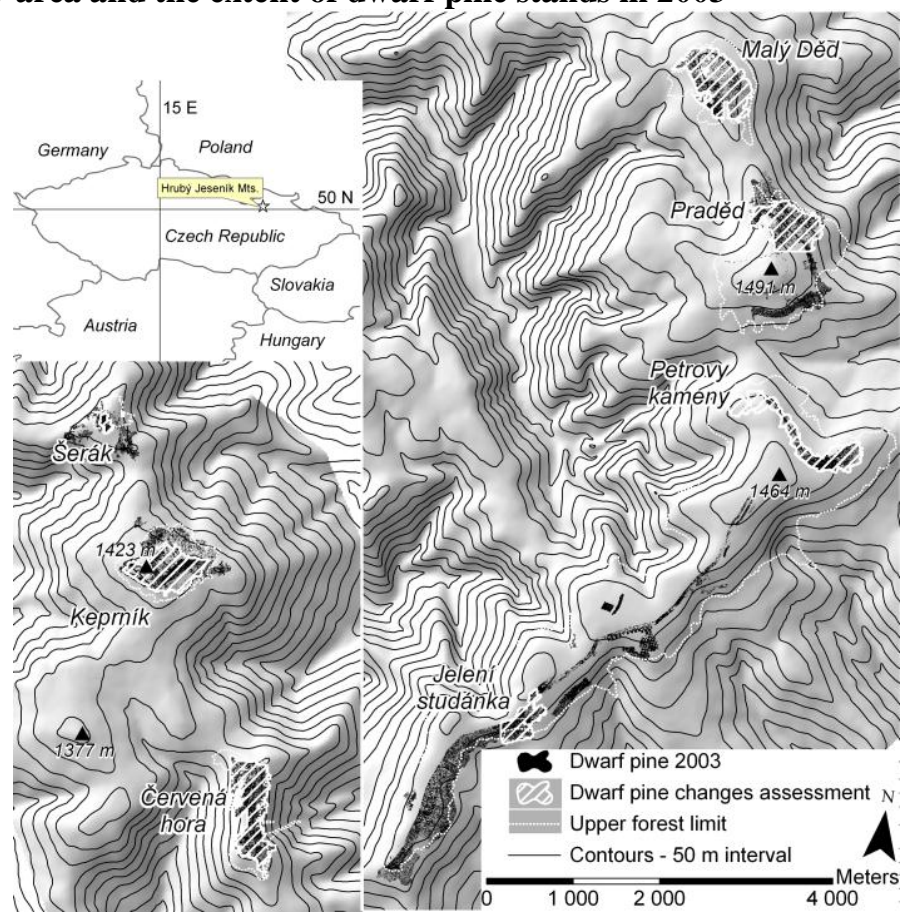

Classification of aerial imagery

We used two classification approaches. In order to determine dwarf pine cover over the whole study area, pixel based classification was applied to recent (2003) imagery. On the other hand, object based classification was used for the assessment of temporal changes in dwarf pine cover on selected areas (Fig. 1). All aerial imagery used in the study were provided as scanned images by Military Office for Geography and Hydrometeorology and their technical parameters are given in Table 1. Images were orthorectified using ground control points derived from current orthogonal images (Czech Geodetic Survey) and a $10 \mathrm{~m}$ resolution DEM created from contour lines $(1: 25000)$ and resampled to final pixel resolution of $0.4 \mathrm{~m}$.

Table 1: Parameters of aerial photographs used in the study

\begin{tabular}{|l|l|l|l|l|l|}
\hline $\begin{array}{l}\text { Year of } \\
\text { acquisition }\end{array}$ & Scale & Type & $\begin{array}{l}\text { Focal length } \\
(\mathrm{mm})\end{array}$ & $\begin{array}{l}\text { Resolution of } \\
\text { scanning }(\mu \mathrm{m})\end{array}$ & Camera \\
\hline 1971 & $1: 15000$ & Panchromatic & 209.83 & 21 & WILD 328 \\
\hline 1973 & $1: 15300$ & Panchromatic & 209.74 & 21 & WILD 328 \\
\hline 2003 & $1: 23000$ & Colour (RGB) & 152.14 & 14 & LMK 2015 \\
\hline
\end{tabular}


Total recent dwarf-pine cover was determined using RGB imagery from the year 2003. Standard supervised classification Maximum Likelihood with four or five classes according the spectral characteristics of each image and finally grouped into two land-cover classes (dwarf-pine and rest) were applied. Partial results of classifications were combined into mosaics covering the whole study area.

Object-based classification was additionally applied for seven selected study sites (188 ha in total, Fig. 1) in order to estimate the precision of supervised classification and to assure comparability of recent and historical images processed solely using object-based techniques. This segmentation approach was based on three layers of colour imagery $(R, G$, B). No filtered layer was used. Classification was performed with the help of training subsets and the segments were classified using the nearest neighbour algorithm. Orthogonal panchromatic black and white images were used as the data source for determining the historical areal extent of dwarf pine. Only limited areas well-representing whole summit regions were selected for analysis and taking into account the minimum sufficient quality of images (Fig. 1, 2).

The object-oriented approach was applied to historical imagery due to its better ability to classify images having limited spectral resolution (Halounová 2004). This approach relies not only on spectral characteristics, but enables the classification of objects based on their spatial, shape and textural properties. Classification was done with Definiens 5.0 software (Definiens, 2006).

Image analysis was conducted through segmentation and classification. A median filter layer with $3 \times 3$ pixel window was created before segmentation in order to suppress local inhomogenities in the image and to increase poor signature space provided by scanned BW photographs (Halounová 2004). Subsequent segmentation was applied to both the original layer (determination of edges) and to the filtered layer rendering compact segments of dwarf-pine polycormons.

Three-level segmentation was applied with the following setting: i) a coarse level with scale values (in terms of Definiens terminology) ranging between 150 and 250 depending on imagery contrast; ii) a detailed scale (values $10-15$ ) to determine individual polycormons, trees, shadows and other features. Additionally, an even more precise, segmentation with scale value equal to 5 was performed for young dwarf pine plantations.

Individual segments were classified based on colour intensity, shape variables (area, shape index) and prevailing orientation on a very fine scale. Individual classes (dwarf pine and shadows) were distributed into groups according to the coarse scale classification. The distinct setting of classification parameters then enabled sorting of segments into individual classes.

The resulting classification was visually checked and any errors were corrected. The proportion of manual correction was quite high, despite the sophisticated methods of classification used. This considerable number of manual corrections needed as well as limitations in image quality was the main reason the analysis was restricted to only selected areas. Nevertheless we consider this method much quicker and reliable than simple manual delineation of dwarf-pine borders.

\section{Classification accuracy}

Object-based classification of current (2003) imagery was manually corrected at the study plots, and is assumed to represent the most precise information about the spatial extent of dwarf pine stands. Then, superposition and comparison of both types of classifications (supervised and object-oriented) returned an error matrix. Two types of errors for both classes (dwarf pine present, dwarf pine absent) were computed: i) omission 
error and the related ,producer's accuracy“, and ii) commission error and the related user's accuracy (Congalton and Green 1999).

\section{Temporal changes}

Finally, the dwarf pine map for years 1971/73 and 2003, both resulting from object-based classification, were overlain and changes in dwarf pine cover were evaluated. Areas selected for analysis included only those stands outside of closed spruce forests, where the classifications errors are higher. Changes were analyzed in $50 \times 50 \mathrm{~m}$ cells, a size that is far larger than the orthorectification and classification error and consistent with the DEM resolution, which is important for the analysis of environmental variables derived from the DEM.

In order to visualize even more subtle dwarf pine spatial shifts, we also depicted changes in a lattice with $15 \mathrm{~m}$ resolution (Fig. 2). This scale is still sufficiently coarse to filter discrepancies caused by orthorectification and imprecise classification.

Overall changes are expressed as area (square meter) per pixel change. Such changes accumulate both the short term decline and expansion over the thirty-year period.

The distance of a randomly placed point to the nearest dwarf pine margin was another variable used to describe the extent of dwarf pine in both time periods. 468 random points were generated outside of dwarf pine polycormons (based on 2003 dwarf pine cover). All points were placed within the minimum convex polygon surrounding the margins of dwarf pine shrubs as were detected at the beginning of the 1970's.

Fig. 2: Changes in dwarf pine cover at study sites from 1971/73 - 2003

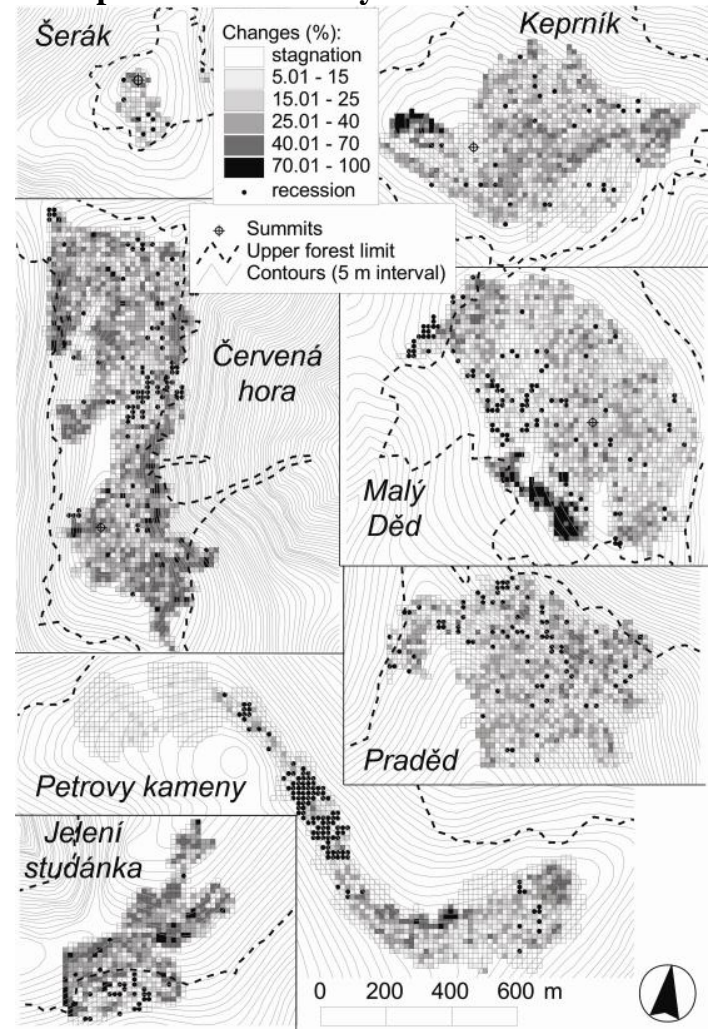




\section{Variables affecting spatial change of dwarf pine stands}

We assumed that the changes in dwarf pine cover are driven by intra-specific competition (canopy closure, patchiness) and by such environmental properties as altitude, snow depth, heat load and available soil water. The effects of these variables were evaluated within a 50 $\mathrm{m}$ lattice, consistent with source data resolution. The following parameters were set for every 50 m square cell: orthogonal area of dwarf pine cover in 1971/73 and in 2003, area change between the two periods, shrub edge length in both periods, number of individual dwarf pine segments, mean altitude, mean topographic wetness index (Beven and Kirkby 1979), mean heat load index (McCune and Keon 2002) and mean stand susceptibility to deflation, which was modeled as a log altitude difference between local altitude maximum (highest point on a maximum slope line) and a given pixel. Variables were derived from the $10 \mathrm{~m}$ resolution DEM and from the created maps of dwarf pine cover.

Since the changes in dwarf pine found were mostly expansions (as opposed to retreat), we focused on relations between dwarf pine expansion (dependent variable) and explanatory variables. The increase in dwarf pine cover was expected to be limited by physically restricted growth where complex margins were present, therefore the difference between the expected and actual increase in dwarf pine cover was set as another dependent variable. This variable was computed as follows: (Area 2003 - Area Simulated + 2500)/2500. The simulated (or potential) area was calculated as the dwarf pine cover in 1971 and 1973 buffered by a 180 and $192 \mathrm{~cm}$ zone respectively, related to the average annual length increment of dwarf pine ( $6 \mathrm{~cm}-\mathrm{Kyncl} 2006)$. This variable equals 1 when the potential and actual increases in dwarf pine cover are identical.

In order to suppress spatial autocorrelation, 130 cells (squares) were randomly selected. Only non-neighbouring cells were selected that covered at least $20 \%$ of each studied area.

The influence of individual variables was analyzed for all study areas together, which includes the whole spectra of stands that are present in the summit part of the Hrubý Jeseník Mts. Using multiple linear regression, the variables with highest explanatory power for dependent variables - dwarf pine cover in 2003, change in dwarf pine cover, or difference between expected and actual expansion were searched for. The dwarf pine cover in 1971/73, edge length in 1971/73 and environmental variables derived from the DEM were considered as explanatory variables. The correlation matrix of explanatory variables was calculated before the analysis and only the non- or weakly correlated variables entered into the model. Normality was tested using the Shapiro-Wilks test of normal distribution. Root square transformation or the arcsine transformation was applied to some variables in order to comply with normal distribution criterion (see the Results section). Hierarchical partitioning (Chevan and Sutherland 1991) enabled decomposition of the total variation explained by the regression model into the independent contributions of individual variables.

Since we found that different initial dwarf pine cover determines the variant influence of other variables, their effect on dwarf pine expansion was additionally assessed separately for both low and high initial dwarf pine canopy cover.

\section{RESULTS}

\section{Classification accuracy}

Overall accuracy of standard Maximum likelihood classification of 2003 RGB imagery approaches $95 \%$ in four cases and was always higher than $85 \%$ (Tab. 2). The relatively lower classification accuracy occurred in areas with a higher proportion of trees (Praděd 
and Malý Děd sites). The overall classification accuracy achieved was $90.1 \%$ and proved using this approach for estimation of recent dwarf pine cover.

Table 2: Error matrix for maximum likelihood classification of RGB images (2003). Manually corrected data derived from object-oriented classification were considered as a reference.

\begin{tabular}{|c|c|c|c|c|}
\hline Locality & Class & $\begin{array}{c}\text { Producer's accuracy } \\
(\%)\end{array}$ & $\begin{array}{c}\text { User's accuracy } \\
(\%)\end{array}$ & $\begin{array}{c}\text { Overall accuracy } \\
(\%)\end{array}$ \\
\hline \multirow{2}{*}{ Šerák } & no-pine & 94 & 95 & \multirow{2}{*}{91} \\
\hline & pine & 71 & 78 & \\
\hline \multirow{2}{*}{ Červená hora } & no-pine & 93 & 99 & \multirow{2}{*}{92} \\
\hline & pine & 85 & 71 & \\
\hline \multirow{2}{*}{ Malý Děd } & no-pine & 88 & 99 & \multirow{2}{*}{89} \\
\hline & pine & 93 & 55 & \\
\hline \multirow{2}{*}{ Jelení studánka } & no-pine & 98 & 92 & \multirow{2}{*}{91} \\
\hline & pine & 58 & 83 & \\
\hline \multirow{2}{*}{ Keprník } & no-pine & 94 & 95 & \multirow{2}{*}{94} \\
\hline & pine & 94 & 93 & \\
\hline \multirow{2}{*}{ Praděd } & no-pine & 84 & 92 & \multirow{2}{*}{86} \\
\hline & pine & 89 & 78 & \\
\hline \multirow{2}{*}{ Petrovy kameny } & no-pine & 94 & 95 & \multirow{2}{*}{93} \\
\hline & pine & 92 & 89 & \\
\hline
\end{tabular}

\section{Recent extent and temporal changes of dwarf pine shrubs}

Dwarf pine recently covers 179.2 ha of the summit areas in the Hrubý Jeseník Mts., from which 153.7 ha is situated above the alpine timberline. The alpine forest-free areas differ both in their extent and in amount of dwarf pine cover (Fig. 1). The areas situated in the northern part of the main ridge of the Hrubý Jeseník Mts. (Šerák, Keprník and Červená hora) have the highest dwarf-pine cover, exceeding more than $30 \%$ of the area above the timberline (Tab. 3). On the contrary, the lowest proportion of dwarf pine is found in the area of Petrovy kameny - Pec $(9.5 \%)$.

Table 3: Extent of forest-free areas above alpine timberline and corresponding dwarf-pine cover (in 2003)

\begin{tabular}{|l|c|c|c|}
\hline \multicolumn{1}{|c|}{ Locality } & $\begin{array}{c}\text { Forest-free area } \\
\text { extent (ha)* }\end{array}$ & $\begin{array}{c}\text { Dwarf pine } \\
\text { extent (ha) }\end{array}$ & $\begin{array}{c}\text { Dwarf pine cover - } \\
\text { relative proportion in \% }\end{array}$ \\
\hline Šerák & 10.76 & 3.67 & 34.1 \\
\hline Keprník & 67.19 & 24.01 & 35.7 \\
\hline Červená hora & 56.38 & 18.38 & 32.6 \\
\hline Malý Děd & 66.93 & 14.40 & 21.5 \\
\hline Praděd & 153.86 & 26.65 & 17.3 \\
\hline Petrovy kameny - Pec & 697.00 & 66.54 & 9.5 \\
\hline
\end{tabular}

*... based on data by Treml and Banas (2000)

The overall increase in dwarf pine cover ranged from $23 \%$ to $94 \%$ in the study period. The lowest increase in dwarf pine cover was at Šerák (23\%), whereas the highest expansion was found at Jelení studánka (Tab. 4). The average annual expansion of dwarf pine in all studied areas ranged around $2 \%$. 
Table 4: Changes in the dwarf pine cover between 1971/73 and 2003

Changes are inferred from square lattice captured on Fig. 1 and 2, which doesn't overlay whole area above the alpine timberline.

\begin{tabular}{|l|c|c|c|c|}
\hline Site name & \multicolumn{2}{|c|}{$\begin{array}{c}\text { Dwarf pine extent } \\
\text { [ha] }\end{array}$} & $\begin{array}{c}\text { Change in percent } \\
\text { of 1971/73 }\end{array}$ & $\begin{array}{c}\text { Mean annual } \\
\text { change in \% }\end{array}$ \\
\hline & $1971 / 73$ & 2003 & & +0.73 \\
\hline Šerák & 1.48 & 1.82 & +23.2 & +2.04 \\
\hline Keprník & 9.33 & 15.43 & +65.3 & +2.46 \\
\hline Červená hora & 8.49 & 15.19 & +78.7 & +2.28 \\
\hline Malý Děd & 7.89 & 13.30 & +68.5 & +1.92 \\
\hline Praděd - Sever & 8.43 & 13.28 & +57.4 & +1.21 \\
\hline Petrovy kameny & 7.09 & 9.68 & +36.4 & +3.13 \\
\hline Jelení studánka & 3.87 & 7.49 & +93.9 & +2.05 \\
\hline All sites in total & 46.59 & 76.20 & +63.5 & \\
\hline
\end{tabular}

Spatial changes in dwarf pine cover revealed small increments for dense stands (Tab. 5). In contrast, considerable expansion was seen in sparse, open canopy shrubs or at the margins of isolated shrubs, where intra-specific competition and physically restricted growth was much lower (Tab. 5). Despite the overall increase in dwarf pine cover, some local reductions were found (Fig. 2), mainly near Petrovy kameny and also, though less pronounced, close to the timberline on the east-facing slope of Červená hora, the western flank of Malý Děd, the northern flanks of Praděd and the east-facing slope of Jelení studánka. Except for the Petrovy kameny site, considerable numbers of Norway spruce trees were common at all of these sites.

Table 5: Results of regression models describing the influence of individual variables on changes in dwarf pine cover between 1971/73 and 2003.

Statistically significant variables are highlighted.

$b^{*} \ldots$ standard regression coefficient; $R^{2} \ldots$ coefficient of determination.

\begin{tabular}{|l|c|c|c|c|c|c|}
\hline & \multicolumn{2}{|c|}{ All } & \multicolumn{2}{c|}{ Initial area $<\mathbf{4 2 0} \mathbf{~ m}^{2}$} & \multicolumn{2}{c|}{ Initial area $\geq \mathbf{4 2 0} \mathbf{~ m}^{2}$} \\
\hline Variable & $\mathbf{b}^{*}$ & $\mathbf{P}$ & $\mathbf{b}$ & $\mathbf{P}$ & $\mathbf{b}^{*}$ & $\mathbf{P}$ \\
\hline Edge length 1973 & $\mathbf{0 . 2 8}$ & $\mathbf{0 . 0 5}$ & $\mathbf{0 . 3 9}$ & $\mathbf{0 . 0 0}$ & - & 0.95 \\
\hline $\begin{array}{l}\text { Free area size 1973 } \\
\text { arcsin transformed) }\end{array}$ & - & 0.48 & - & 0.75 & $\mathbf{0 . 3 5}$ & $\mathbf{0 . 0 0}$ \\
\hline Number of segments & $\mathbf{0 . 3 1}$ & $\mathbf{0 . 0 0}$ & - & 0.08 & - & 0.24 \\
\hline Heat load index & $\mathbf{- 0 . 2 8}$ & $\mathbf{0 . 0 1}$ & $\mathbf{- 0 . 3 2}$ & $\mathbf{0 . 0 1}$ & - & 0.52 \\
\hline Topographic wetness index & - & 0.06 & - & 0.25 & - & 0.22 \\
\hline Altitude & $\mathbf{- 0 . 3 3}$ & $\mathbf{0 . 0 0}$ & $\mathbf{- 0 . 3 2}$ & $\mathbf{0 . 0 2}$ & - & 0.35 \\
\hline $\begin{array}{l}\text { Stand susceptibility to } \\
\text { deflation }\end{array}$ & - & 0.88 & - & 0.89 & - & 0.43 \\
\hline Full model & $\begin{array}{l}\text { Adjusted } \\
\mathrm{R}^{2}=0.26, \mathrm{p}<0.01\end{array}$ & $\begin{array}{l}\text { Adjusted } \\
\mathrm{R}^{2}=0.49, \mathrm{p}<0.01\end{array}$ \\
\hline
\end{tabular}

The densest dwarf pine stands covered forest-free areas of the Praděd and Červená hora sites at the beginning of the studied period. These stands also had the smallest gaps within dwarf pine stands (Fig. 3). On the contrary, dwarf pine communities at Keprník Mt. were relatively open with large gaps. The most considerable reduction in gap size during the study period was found at the Šerák and Malý Děd sites (Fig. 3). 
Fig. 3: Distance to the nearest dwarf pine margin in 1971/73 and 2003

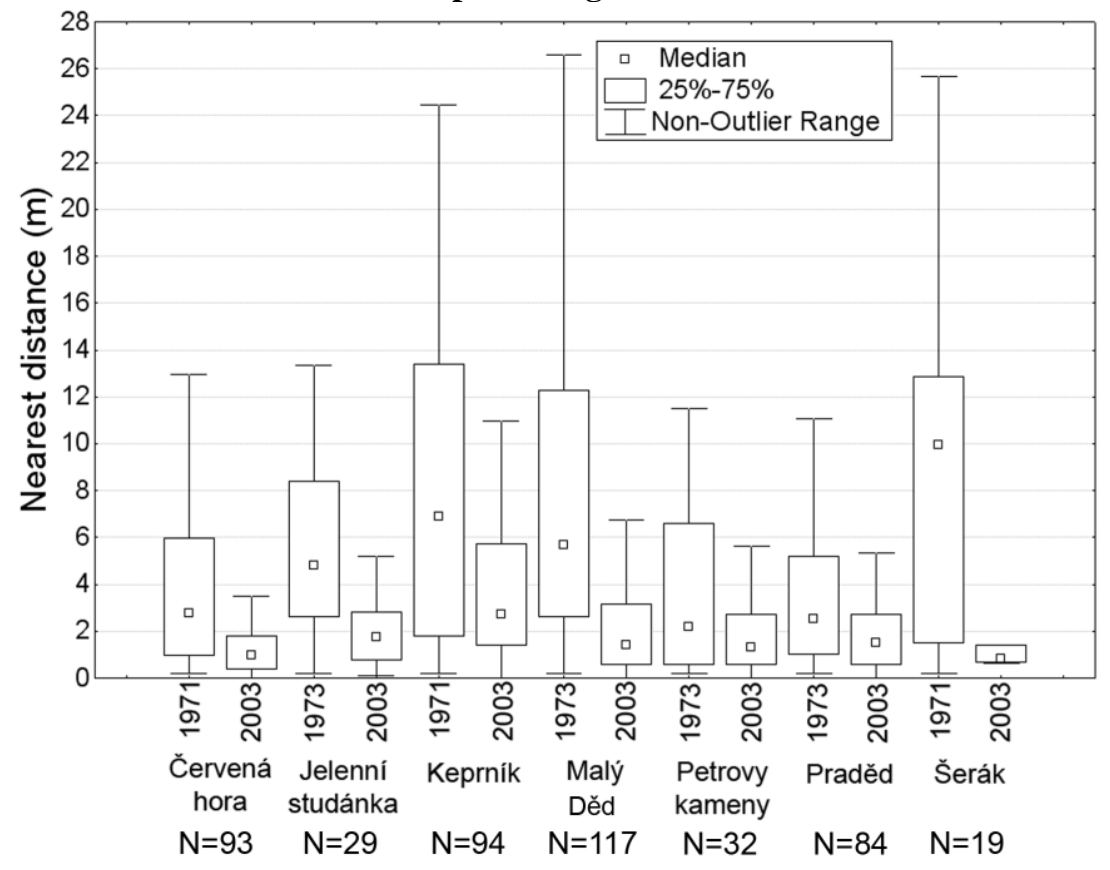

Variables affecting the spatial pattern of dwarf pine expansion

The dwarf pine cover in the year 2003 is mainly dependent on the previous extent of stands in $1971 / 73\left(b^{*}=0.77 ; \mathrm{P}<0.01\right)$; in other words, the larger the pine area in $1971 / 73$, the larger was its cover in 2003. Initial (1971/73) edge length is strongly correlated with pine area $(r=0.79)$, and thus longer edge length in 1971/73 resulted in higher dwarf pine cover in 2003. The initial number of pine segments affects the recent dwarf pine cover as well $\left(b^{*}=0.15 ; \mathrm{P}<0.01\right)$, and of the environmental variables only altitude plays a role $\left(b^{*}=-0.15 ; \mathrm{P}<0.00\right)$.

If the change in dwarf pine cover is taken as a dependent variable, then the number of dwarf pine segments and altitude are the most influential variables (Tab. 5). A higher number of segments results in a higher expansion of dwarf pine, and this expansion was also more pronounced at lower elevations. Dwarf pine expanded significantly less at sites with high heat load. Also, the initial edge length has a statistically significant effect. This variable, however, is correlated with the number of segments $(r=0.45)$. The influence of other variables on the dwarf pine expansion is not significant.

The effect of the above-mentioned variables is changeable in relation to initial dwarf pine cover (Tab. 5). We expected that until the certain canopy cover is achieved, the stand expansion would be driven mainly by edge length and other textural and environmental variables. However after reaching the point, where expansion is physically limited, only the variables related to available space for expansion were supposed to be more important. In both periods (1971/73 and 2003), there is a strong linear relationship between dwarf pine cover in assessed square cells and corresponding edge length approximately to the value of $420 \mathrm{~m}^{2}$. Then, fluctuating or decreasing values of edge length with increasing dwarf pine cover could be observed, which indicate physical restriction of growth. Therefore we 
divided analyzed data into two subsets based on initial area (or edge length) within the square cell.

Resulting regression models show that edge length, heat load index and altitude affect the expansion especially when the initial dwarf pine cover (or edge length, $r=0.79$ ) is low (dwarf pine cover $\leq 420 \mathrm{~m}^{2}, \mathrm{n}=60$ ). The regression model including these variables then convincingly explains the changes in dwarf pine expansion. On the contrary, these variables lose their explanatory power when the initial dwarf pine cover in 1971/73 is moderate or high (dwarf pine cover $>420 \mathrm{~m}^{2}, \mathrm{n}=70$ ). In these cases, the free-area size (or initial dwarf pine cover - both variables describe the same quality) is the only influential variable.

We know, however, that the edge length variable deforms the relationships analyzed, because the growth of complex dwarf pine margins is physically restricted. This is not a case of a difference between expected and actual increase in dwarf pine cover. Values of this variable are again influenced by initial edge length and altitude (both with negative relation) (Tab. 6). The whole model explains $35 \%$ of the variability, of which $29 \%$ consists of edge length and $6 \%$ of mean altitude, as indicated by hierarchical partitioning. Edge length is, however, strongly correlated with free area cover $(\mathrm{r}=-0.79)$, and this should be taken into account.

Table 6: Results of the regression model describing the influence of individual variables on differences between expected and actual increase in dwarf pine cover Statistically significant variables are highlighted. $\mathrm{b}^{*} \ldots$ standard regression coefficient; $\mathrm{R}^{2} \ldots$ coefficient of determination.

\begin{tabular}{|l|c|c|}
\hline Variable & b $^{*}$ & P \\
\hline Edge length 1973 & $\mathbf{- 0 . 7 1}$ & $\mathbf{0 . 0 0}$ \\
\hline Free area size 1973 (arcsin transformed) & - & 0.33 \\
\hline Number of segments & - & 0.19 \\
\hline Altitude & $\mathbf{- 0 . 3 2}$ & $\mathbf{0 . 0 0}$ \\
\hline Heat load index & - & 0.15 \\
\hline Topographic wetness index & - & 0.46 \\
\hline Stand susceptibility to deflation & - & 0.55 \\
\hline Full model & Adjusted $\mathrm{R}^{2}=0.35, \mathrm{p}<0.01$ \\
\hline
\end{tabular}

\section{DISCUSSION}

\section{Dwarf pine stand dynamics}

The high accuracy of aerial photograph classification resulting from spectrally well differentiated classified objects - dwarf pine polycormons against contrasting alpine grasslands - enabled us to perform a quantitative assessment of dwarf pine stand spatial dynamics. The annual rate of stand expansion reached 1-3\% at our study sites. In total, the expansion ranged between $23 \%$ (Šerák site) and 78\% (Červená hora site). This is rather low compared to results of Souček et al. (2001), who found a rate of dwarf pine stand expansion between 46-90\% within 17 years in the Western Giant Mts. We assume that the difference might be due to the uneven spatial pattern of assessed stands at the very beginning. In the Western Giant Mts. dwarf pine stands were rather open, enabling lateral spreading in comparison to sites in the Hrubý Jeseník Mts. Wild (2006a) compared the rate of native and 
planted dwarf pine expansion, also in the Giant Mts. Over 35 years, the native stands expanded $0.93-1.17 \%$ a year and planted stands $0.6-16 \%$ a year.

The rate of dwarf pine expansion significantly varied among study sites in the Hrubý Jeseník Mts. We suppose that these differences were caused by dissimilar initial conditions - varying stand canopy cover (affecting intraspecific competition), the different origins of planted dwarf pine as suggested by Hošek (1964), the uneven age of dwarf pine and probably also by different Norway spruce canopy cover at the sites.

The effects of different stand age were clear in the southeastern part of the Petrovy kameny site, the eastern part of Keprník and at the Jelení studánka site, where young dwarf pine stands rapidly expanding in comparison with old stands.

Stand age is well correlated with stand canopy cover. Young planted stands with open canopy usually expand faster. The closed canopy found at the Šrák site was apparently a limiting factor for expansion. Closed stands that have been non-expanding since the 1970's as well as isolated fast expanding polycormones were found at this site, as well as at the Jelení studánka site and less distinctively at the Červená hora and the Keprník sites. Rather open stands that were evenly expanding over the study sites were found on Praděd and Malý Děd. At the Petrovy kameny site, closed stands have occurred since the 1970's, except at the southeastern tip. These stands locally declined, however, probably due to attacks of the European pine sawfly (Neodiprion sertifer) or were eliminated to enlarge ski slopes.

\section{Reasons of uneven dwarf pine stand expansion}

As expected, the current dwarf pine cover mostly depends on its extent in the year 1971/1973. Explaining the variations in the stand expansion is more challenging, however. Above all, this variation is affected by the spatial pattern of stands as manifested by the number of segments and edge length in the initial period. More complex margins of scattered dwarf pine polycormons evidently accelerate lateral spreading. Expansion of dwarf pine was faster at low altitudes and at "cold sites" (with low heat load). The negative relation of dwarf pine expansion to heat load could be attributed to the higher number of days with snow cover on north-facing slopes possibly impeding soil freezing and winter desiccation, which are contrariwise stronger on south-facing slopes (Tranquillini 1979, Cairns 2001). Dwarf pine in the Hrubý Jeseník Mts. grows on sites that are far below its physiological limits, which might be another reason why south facing slopes were not preferred. In this context, it is difficult to explain the faster expansion of dwarf pine at low elevations, especially when there is no effect of stand susceptibility to deflation on dwarf pine spreading. Nevertheless, we suggest that strong snow deflation and the related climatic extremes characteristic for the highest elevations (Praděd, Petrovy kameny, Keprník) play a role, as was shown already by Kyncl (2006), who found significantly lower terminal increments of branches on extremely deflated sites. Ridge parts of other studied sites (Šerák, Malý Děd and Jelení studánka) are not as wind-swept, and this could be one reason why the variable of stand susceptibility to deflation, which was expressed as altitudinal difference, failed. Moreover, this result could also be caused by the sample plot size (50x50 m), with the windward and leeward sites close to mountain tops often being included together.

The expansion of open canopy stands showed a positive relation to variables describing stand texture (margin length in the year 1971/1973 and the number of segments). Open stands are less physically restricted in expansion, so the fine-grained and complex character of dwarf pine stands favors their lateral spreading. The relation of increases in dwarf pine cover to heat load and altitude was explained above. 
The growth of closed canopy stands is, on the contrary, controlled mainly by the extent of open space towards which the stand could expand. Other textural and topographic variables do not play a significant role. This suggests that intraspecific competition leads to limitation of stand growth, as was shown by Wild and Winkler (2008).

The analysis of differences between the expected and actual rate of dwarf pine expansion offered us a completely different view on the increase in dwarf pine cover. Expansion was higher than expected at sites with low initial edge length in 1971/73. This variable, however, is strongly correlated with free area size and therefore we suggest that (a) there was an even greater potential for spreading than the modeled $6 \mathrm{~cm}$ per year, and (b) generative reproduction has to be taken into account. The hypothesis regarding the greater spreading potential is also supported by the higher-than-expected expansion at lower elevations, where Kyncl (2006) determined a terminal increment of pine branches approaching $8 \mathrm{~cm}$ per year.

Locally, there are other factors not included in this analysis affecting the rate of expansion, such as type of ground vegetation and Norway spruce canopy cover. The relations of Norway spruce canopy cover and dwarf pine expansion/retreat were well documented at the Jelení studánka site. In the contact zone between dwarf pine and spruce stands, where the spruce formed isolated enclaves, the most extensive decrease of dwarf pine was found. This has also been reported elsewhere in the Sudetes Mts. - Kozí hřbety in the Giant Mts. (Jeník and Lokvenc 1962), or observed by the authors in area of Malý Sněžník in the Králický Sněžník Mts.

The expansion of dwarf pine stands is also affected by ground vegetation cover and type, both influencing the generative reproduction (Dullinger et al. 2003, Wild 2006a). These factors were not tested due to the lack of a detailed vegetation map. We could only approximate the influence using habitat maps prepared for the NATURA 2000 delineation. Unlike the other localities, the Keprník and Petrovy Kameny sites are dominantly covered by Avenella flexuosa and Festuca supina (NATURA 2000 habitat code 6150 Alpine grasslands), creating good germination conditions for dwarf pine (Treml and Šenfelder 2007). Moreover, the highest number of young seedlings of dwarf pine has been recently recorded at these sites (Treml and Šenfeldr, 2007). Therefore, the fast expansion of gappy dwarf pine stands at the Keprník site is in agreement with the hypothesis of auxiliary role of generative reproduction.

The extent of alpine enclaves above the upper forest limit - implication for nature conservation

The extent of forest-free alpine enclaves is crucial for the existence of a number of threatened species. This has been demonstrated for the Hrubý Jeseník Mts. for insects by Kuras and Helová (2002) and for plant diversity by Zeidler et al. (2009, 2010). Areas included in this study are characterized by an extensive cover of dwarf pine stands (being most extensive at the Keprník, Šerák and Červená hora sites) that continue to quickly expand ( $2 \%$ a year). At the Keprník site, the dwarf pine stands are rather concentrated in closed patches, leaving relatively enough open space; however, dwarf pine stands at the Červená hora and Šerák sites are spread all over. The lack of open non-forested alpine enclaves thus might threaten valuable species, as was demonstrated by Kuras (2007), who stated that the extent of dwarf pine stands and the extent of alpine enclaves are well correlated with the diversity and abundance of day butterflies.

The size of open spaces is also an important factor influencing plant species diversity (Soukupová et al. 2001). The diversity of the Juncion-trifidi and Nardo-Caricion rigidae plant species studied by Zeidler et al. (2010) was closely related to the edge distance of 
dwarf pine stands. The smaller the gap was, the lower the plant diversity. Sites having only small patches of open enclaves are probably strongly endangered by the disappearance of alpine species sensitive to light conditions.

\section{CONCLUSIONS}

Dwarf pine stands increased their cover by 63 percent between 1971/1973 and 2003, with an annual expansion of approximately 2 percent. The sites analyzed include more than one third of all dwarf pine stands in the Hrubý Jeseník Mts., represent both ,average“ and "extreme" sites from the view point of snow pack depth and include plantations of diverse age. Thus, we consider the results to be representative and valid for the Hrubý Jeseník Mts. as a whole. Variability in the expansion of stands is significantly influenced by intraspecific competition since closed stands expand less or show no expansion compared to open stands. Altitude and heat load as a proxy for annual near-ground temperature regime are the only influential environmental variables. Dwarf pine stands expand more at lower altitudes, probably due to the less extreme microclimate. Low values of the site heat load support faster dwarf pine expansion. We suggest that greater and longer snow cover at sites with low heat load probably results in lower winter desiccation, which is more typical for south facing slopes. More intense dwarf pine expansion than expected was characteristic mainly for open stands and lower altitudes. This might be explained by the less extreme environment and possibly also by the certain role of generative reproduction.

Heliophilous alpine species are most endangered in alpine enclaves with extensive dwarf pine stands and small gaps. This is especially the case for the Šerák, Červená hora, Malý Děd and Keprník areas.

\section{ACKNOWLEDGEMENTS}

This study was supported by grant project VaV SM/6/70/05 provided by Czech Ministry of Environment. Václav Treml, Tomáš Chuman and Markéta Potǔčková were further funded by the institutional research project MSM 0021620831. Jan Wild was supported by projects no. AV0Z60050516. The authors wish to thank Irena Kopalová for help with classification of aerial imagery and to David Hardekopf for improving English language. In addition, the comments of the anonymous reviewers on an earlier version of the manuscript are appreciated.

\section{REFERENCES}

Beven, K.J., Kirkby, M.J. (1979). A physically based, variable contributing area model of basin hydrology. Hydrological Sciences Bulletin, 24:43-69.

Bureš, L., Burešová, Z. (1989). Geobotanická expertiza k provádění experimentální likvidace kleče v SPR Malá kotlina. Manuskript, Správa CHKO Jeseníky, KSPPOP Ostrava.

Businský, R. (1998). Agregát Pinus mugo v bývalém Československu: taxonomie, rozšírení, hybridní populace a ohrožení. Zprávy České Botanické Společnosti, 33: 29-52.

Cairns, D. (2001). Patterns of winter desiccation in krummholz forms of Abies lasiocarpa at treeline sites in Glacier national park, Montana, USA. Geografiska Annaler, 83A: 157-168. 
Chevan, A., Sutherland, M. (1991). Hierarchical partitioning. American Statistician, 45: 90-96.

Congalton, R.G., Green, K. (1999). Assessing the accuracy of remotely sensed data. Principles and Practices. Lewis Publ., Boca Raton, Florida.

Definiens (2006). Definiens Professional 5 user guide. Definiens AG, Munich.

Dullinger, S., Dirnböck, T. \& Grabherr, G. (2003). Patterns of shrub invasion into high mountain grasslands of the northern calcareous Alps, Austria. Arctic, Alpine and Antarctic Research, 35: 434-441.

Halounová, L. (2004). The automatic classification of b\&w photos. The International Archives of the Photogrammetry, Remote Sensing and Spatial Information Sciences 34, Part 30.

Hamerník, J., Musil, I. (2007). The Pinus mugo complex - its structuring and general overview of the used nomenclature. Journal of Forest Science, 53: 253-266.

Hošek, E. (1964). Zalesňování horských holí na Králickém Sněžníku a Keprníku kolem r. 1900. Časopis Slezského Muzea (C), 3: 65-73.

Hošek, E. (1973). Vývoj dosavadního hospodaření v nejvyšších polohách Jeseníků a jeho vliv na horní hranici lesa. Campanula, 4: 69-81.

Jeník, J. (1961). Alpinská vegetace Krkonoš, Králického Sněžníku a Hrubého Jeseníku. Academia, Praha.

Jeník, J., Lokvenc, T. (1962). Die alpine Waldgrenze im Krkonoše Gebirge. Rozpr. Čs.Akad. věd, Praha, ser. Math. - natur., 72/1: 1-65.

Kuras, T. (2007). Vliv kleče na entomofaunu. In: Hošek, J. (Ed.): Vliv výsadeb borovice kleče (Pinus mugo) na biotopovou a druhovou diverzitu arkto-alpinské tundry ve Východnich Sudetech (CHKO Jeseníky, NPR Králický Sněžník). Návrh managementu těchto porostů. Závěrečná zpráva z projektu VaV SM/6/70/05. Ministerstvo životního prostředí, Praha

Kuras, T., Helová, S. (2002). Relict occurrence of the leaf-roller Sparganothis rubicundana in Central Europe (Lepidoptera, Tortricidae). Časopis Slezského Muzea Opava (A), 51: 199-204.

Kuras, T., Beneš, J. \& Konvička, M. (2001). Behaviour and within-habitat distribution of adult Erebia sudetica sudetica, endemic of the Hruby Jesenik Mts., Czech Republic (Nymphalidae, Satyrinae). Nota Lepidopterologica, 24: 69-83.

Kyncl, T. (2006). Hodnocení růstové rychlosti klečových porostů. In: Hošek, J. (Ed.): Vliv výsadeb borovice kleče (Pinus mugo) na biotopovou a druhovou diverzitu arkto-alpinské tundry ve Východních Sudetech (CHKO Jeseníky, NPR Králický Sněžník). Návrh managementu těchto porostů. Zpráva z projektu VaV SM/6/70/05. Ministerstvo životního prostředí, Praha.

McCune, B., Keon, D. (2002). Equations for potential annual direct incident radiation and heat load. Journal of Vegetation Science, 13: 603-606.

Novák, J., Petr, L. \& Treml, V. (2010). Late-Holocene human-induced changes to the extent of alpine areas in the East Sudetes, Central Europe. The Holocene, 20: 895-905.

Sokol, F. (1965). Vliv př́rodního prostředí a lidské činnosti na vznik svahových sesuvů a dosavadni zkušenosti sjejich rekultivací v Hrubém Jeseniku. Disertační práce MZLU Brno. 
Souček, J., Lokvenc, T., Vacek, S. \& Štursa, J. (2001). Site and stand conditions of dwarf pine stands. Opera Corcontica, 38: 43-61.

Soukupová, L., Frantík, T. \& Jeník, J. (2001). Grasslands versus krummholz in arcticalpine tundra of the Giant Mountains. Opera Corcontica, 38: 63-76.

Štursa, J. (1966). Pinus mugo ssp. Pumilio (Haenke) Franco ve východních Krkonoších. Opera Corcontica, 7-8: 157-178.

Tranquillini, W. (1979). Physiological ecology of the alpine timberline. Tree existence at high altitudes with special reference to the European Alps. Ecological studies, 31: $131 \mathrm{pp}$.

Treml, V., Banaš, M. (2000). Alpine timberline in the High Sudetes. Acta Universitatis Carolinae Geographica, 15: 83-99.

Treml, V., Šenfelder, M. (2007). Generativní šiřrení borovice kleče na příkladu vybraných lokalit Hrubého Jeseníku (Keprník, Větrná louka). In: Hošek, J. (Ed.): Vliv výsadeb borovice kleče (Pinus mugo) na biotopovou a druhovou diverzitu arkto-alpinské tundry ve Východnich Sudetech (CHKO Jeseniky, NPR Králický Sněžnik). Návrh managementu těchto porostů. Zpráva z projektu VaV SM/6/70/05. Ministerstvo životního prostředí, Praha.

Wild, J. (2006). Krummholz and grassland in the summit plateaux of the Krkonoše Mountains: their interactions and long-term dynamics. Disertační práce, Ústav životního prostředí Př́rodovědecké fakulty UK, Praha.

Wild, J., Wildová, R. (2002). Interactions between dwarf pine shrubs and grassland vegetation under different management. Opera Corcontica, 39: 17-34.

Wild, J., Winkler, E. (2008). Krummholz and grassland coexistence above the forest-line in the Krkonoše Mountains: Grid-based model of shrub dynamics. Ecological Modelling, 213: 293-307.

Zeidler, M., Banaš, M. \& Ženatá, M. (2009). Ecological conditions and the distribution of alpine juniper (Juniperus communis subsp. alpina) in the Hrubý Jeseník Mts. Biológia, 64: 687-693.

Zeidler, M., Banaš, M.. Duchoslav, M. \& Lešková, M. (2010). Vliv vysazených klečových porostů na alpínskou vegetaci v Hrubém Jeseníku. Př́roda, 29: 37-50. 